\title{
Respon Penawaran Padi/Beras di Indonesia
}

\author{
Julia Hutauruk \\ Program Studi Agribisnis, Fakultas Pertanian Universitas Katolik Santo Thomas Medan \\ Email : juliahutauruk@ymail.com
}

\begin{abstract}
Abstrak
Padi / beras merupakan komoditi yang paling penting perannya di Indonesia karena merupakan sumber pendapatan dan kesempatan kerja bagi sebagian besar pernduduk, merupakan komponen penting dalam pengeluaran rumahtangga, sehingga kedua hal ini menyebabkan beras menjadi penentu stabilitas ekonomi dan politik nasional. Dalam dua puluh tahun terakhir, luas lahan di Indonesia menyusut. Menurut perkiraan, penyusutan terjadi sampai dengan 90.000 ha/thn. (terutama di jawa). Penyusutan lahan tersebut menjadi kontribusi utama dalam penyusutan produksi beras nasional sehingga impor beras meingkat dari tahun ke tahun.Peningkatan produksi padi merupakan upaya memenuhi kebutuhan masyarakat dan mengurangi impor. Studi ini dilakukan dengan menganalisa factor yang mempengaruhi penawaran padi/ beras di Indonesia dan respon penawaran didekati dengan menganalisa elastibilitas jangka pendek maupun jangka panjang. Hasil studi menunjukkan bahwa pengaruh harga signifikan terahadap produktivitas tetapi tidak signifikan pada luas areal. Dalam jangka pendek, elastisitas penawaran yang diwakili oleh luas areal ( 0,079 dalam jangka pendek dan 0,151 dalam jangka panjang) lebih kecil daripada elastisitas produktivitas $(0,049$ dalam jangka pendek dan 0,272 dalam jangka panjang. Elastisitas penawaran lebih kecil disbanding dengan elastisitas jangka panjang. Elasitisitas penawaran padi pada sawah di Indonesia adalah Inelastis baik dalam jangka pendek maupun dalam jangka panjang.
\end{abstract}

Kata kunci : respon penawaran, produktivitas, luas lahan

\begin{abstract}
Rice is the most important commodity in Indonesia because it is a source of income and employment opportunities for most farmers, is an important component in household spending, so both of these causes rice to be the determinant of national economic and political stability. In the last twenty years, indonesia's land area has shrunk. According to estimates, depreciation occurs up to 90,000 ha / yr. (especially in Java). The depreciation of the land is the main contribution in the shrinkage of national rice production so that rice imports increase from year to year. Increasing rice production is an effort to meet the needs of the community and reduce imports. This study was conducted by analyzing the factors that affect rice supply in Indonesia and the offer response approached by analyzing short-term and long-term elastibilities. The results showed that the influence of significant price faced productivity but not significant on the area. In the short term, the elasticity of the offering represented by the area ( 0.079 in the short term and 0.151 in the long run) is less than the elasticity of productivity (0.049 in the short term and 0.272 in the long run. The elasticity of the offer is smaller compared to long-term elasticity. The elasitisity of rice supply to rice fields in Indonesia is inelastis both in the short term and in the long term.
\end{abstract}

Keywords : supply response, productivity, land area

\section{PENDAHULUAN}

Beras adalah komoditi pangan yang penting peranannya bagi pemerintah maupun rakyat Indonesia, pertama karena padi/beras merupakan komponen utama dalam pengeluaran rumah tangga, dikarenakan beras merupakan kebutuhan pokok masyarakat. Kedua beras juga sebagai sumber kalori dan protein. Ketiga beras merupakan sumber pendapatan dan kesempatan kerja bagi sebagian besar penduduk dan keempat penentu stabilitas ekonomi dan politik nasional. Upaya peningkatan produksi demi tercapainya swasembada yang telah dicapai, tetapi diubah dari laju pertumbuhan penduduk yang tinggi, pergeseran konsumsi pangan pokok dan non pokok, serta beberapa kendala menyebabkan Indonesia masih tergantung pada impor.
Jadi, penyediaan kebutuhan beras dilakukan dengan dua cara yakni dengan memproduksi sendiri di dalam negri dengan memanfaatkan sumberdaya maupun teknologi yang ada, ataupun dengan mengimpor dari negara lain.

Masalah lain adalah penyusutan lahan yang diperuntukkan untuk penanaman padi dari tahun ke tahun menyusut tajam. Menurut Jalil S (2018) setiap tahunnya sekitar 150-200 ribu ha sawah berubah peruntukkannya untuk kepentingan lain. Penyusutan yang dominan yang terjadi di Pulau Jawa ini, umumnya disebabkan oleh pertumbuhan industri, jalan dan perumahan, padahal lahan di Pulau Jawa terkenal dengan prestasi lahan dan petani dapat produktifitas yang tinggi dan sampai saat ini produktifitas padi di Pulau Jawa masih jauh lebih tinggi daripada di Luar Pulau Jawa. Menurut Amelia 
dkk (2019), bahwa produktifitas padi sawah di Luar Jawa 30\% lebih rendah dari pada di Pulau Jawa. Dan lahan sawah di Pulau Jawa masih terus bergeser menjadi lahan industri dan jasa hingga pada era pembangunan saat ini. Kawasan Luar Pulau Jawa dipercaya akan menjadi tumpuan penghasil produksi baik melalui ekstensifikasi dan intensifikasi.

Namun peningkatan serta keberlanjutan produksi padi di Indonesia sangat ditentukan oleh partisipasi petani dalam program intensifikasi dan ekstensifikasi yang telah dicanangkan pemerintah pada saat ini. Pemerintah telah mengucurkan dana investasi yang besar untuk meningkatkan produksi beras nasional, tapi upaya ini akan kurang efektif jika tidak diikuti oleh semangat motivasi petani sendiri dalam upaya meningkatan peningkatan partisipasinya demi peningkatan produksi . Tentu saja petani akan bersemangat jika keterlibatannya dapat menguntungkan bagi petani dan keluarganya.

Dari sisi ekonomi, partisipasi ini dapat dilihat dari respon penawaran petani terhadap stimulus harga maupun variabel lainnya. Informasi tentang respon produktivitas dan areal panen yang mewakili respon penawaran akan dapat menjadi bahan pertimbangan pemangku jabatan untuk membuat kebijakan yang akan mendukung peningkatan produksi padi dan beras pada masa kini dan masa yang akan datang.

\section{METODE PENELITIAN}

Model yang digunakan dalam pendugaan adalah model penyesuaian parsial yang digunakan atau yang biasa digunakan pada berbagai studi respon penawaran. Model distribusi bedakala, penyesuaian parsial dikembangkan oleh Nerlove (1958) paling banyak digunakan dalam studi respon penawaran.

Menurut Ghatak dan Inversen (1984) bahwa dalam bentuk yang sederhana output (Q) dispesifikasikan sebagai perkalian antara luas Panen (A) dengan produktivitas (Y).

$\mathrm{Q}=\mathrm{A} \times \mathrm{Y}$

Dalam bentuk (Ln)

Perubahan produktifitas karena perubahan harga terdiri dari perubahan produktifitas secara parsial terhadap harga dan perubahan produksi karena terjadi perubahan areal terhadap perubahan harga.

$\frac{1}{Q} x \frac{d Q}{d P}=\frac{1}{A} x \frac{d A}{d P}+\frac{1}{Y} x \frac{d y}{d P}$

Maka

$\frac{d y}{d P}=\frac{\delta y}{\delta P}+\frac{d y}{d A} x \frac{\delta Q}{\delta P}$

$\frac{1}{Q} x \frac{d Q}{d P}=\frac{1}{A} x \frac{d A}{d P}+\frac{1}{Y} x \frac{d Y}{d P}+\frac{\delta y}{\delta A}+\frac{\delta A}{\delta P}$ $\frac{d Q}{d P} x \frac{P}{Q}=\frac{d A}{d P} x \frac{P}{A}+\frac{d Y}{d P} x \frac{P}{Y}+\frac{d y}{d A} x \frac{d A}{d P} x \frac{P}{Y} x \frac{A}{Y}$

$\frac{d Q}{d P} x \frac{P}{Q}=\frac{d Y}{d P} x \frac{P}{Y}+\frac{d A}{d P} x \frac{P}{A}\left(P+\frac{d Y}{d A} x \frac{A}{Y}\right)$

Bila dinyatakan dalam elastisitas

$\mathrm{E}(\mathrm{Qp})=\mathrm{E}(\mathrm{Y}, \mathrm{P})+\mathrm{E}(\mathrm{A}, \mathrm{P})(1+\mathrm{E}(\mathrm{Y}, \mathrm{A}))$

$\mathrm{E}(\mathrm{Qp})=$ Elastisitas respon penawaran

$\mathrm{E}(\mathrm{A}, \mathrm{P})=$ Luas Areal terhadap harga Elastisitas

$\mathrm{E}(\mathrm{Y}, \mathrm{A})=$ Elastisitas Produktifitas terhadap Areal

Selanjutnya untuk memperoleh ukuran kuantitatif respon suatu fungsi terhadap faktor yang mempengaruhi digunakan konsep elastisitas. Untuk model dinamis dapat dihitung elastisitas jangka pendek dan panjang.

Elastisitas jangka pendek :

$\mathrm{ESR} \quad=\frac{d Y}{X t} x \frac{X t}{Y t}$

$$
=b x \frac{X t}{Y t}
$$

Elastisitas jangka panjang:

ELR $=\frac{E_{S R}}{1-b l}$

Dimana: :

ESR = Elastisitas jangka pendek peubah endogen terhadap peubah eksogen

ELR $=$ Elastisitas endogen terhadap peubah eksogen

$\mathrm{b} \quad=$ Koefisien dugaan peubah eksogen

bl = Koefisien dugaan dari peubah Lag

$\mathrm{Xt}=\mathrm{Rata}-$ rata peubah eksogen $\mathrm{Yt}=$ rata - rata peubah endogen

Luas Areal dirumuskan sebagai areal panen padi merupakan fungsi dari harga beras, harga pupuk, harga komoditi yang berkompetisi dengan padi dan luas areal padi tahun sebelumnya.

Petani diasumsikan berpikir rasional untuk menyesuaikan luas areal padi yang ada pada saat ini berdasarkan harga periode sebelumnya, sehingga persamaan luas areal padi dirumuskan sebagai berikut.
A1 = b0 + HBRt $1+$ b2 HJGt + b3 HPUt + Ut
Dimana
A = luas areal panen padi tahunan $\mathrm{t}$ (000ha)
HBRt-1 = Harga padi tahun sebelumnya
HJGI =Harga komoditi yang berkompetisi dengan padi $(\mathrm{Rp} / \mathrm{kg}$
Ut $\quad=$ Peubah pengganggu

Respon areal ini dikombinasikan dengan model persamaan parsial nerlove.

$\mathrm{A}^{\prime}=\mathrm{Q}+\mathrm{Q} 1$ HBRt$-1+\mathrm{Q} 2 \mathrm{HJGt}+\mathrm{Q} 3 \mathrm{HPUt}+\mathrm{Ut}$

Dimana

$A^{\prime} t=$ Areal panen yang diharapkan pada tahun $t$ 
Perubahan areal panen yang sebenarnya merupakan fraksi dari perubahan yang dinginkan. Ada masalah disini pada A't yang tidak dapat diamati/ Dengan model penyesuaian parsial hal ini dapat diselesaikan.

$$
\text { At }=\text { At }-1=d(\text { At-At-1) }
$$$$
\text { Di mana }
$$

$0<\mathrm{d}<1$. Jika persamaan (2) disubstitusikan ke dalam (3) makan akan diperoleh:

At $=\mathrm{d}\{\mathrm{a} 0+\mathrm{a} 1$ HBRt $-1+\mathrm{a} 2 \mathrm{HJGt}+\mathrm{a} 3$ HPUt $+\mathrm{UJ}+(1-$ d) At-1

$\mathrm{At}=\mathrm{a} 0+\mathrm{a} 1 \mathrm{~d}$ HBRt $-1+\mathrm{a} 2 \mathrm{~d}$ HJGt $+\mathrm{a} 3 \mathrm{~d}$ HPUt $+\mathrm{a} 4 \mathrm{~d}$ At-1+et

Tanda yang diharapkan a1 $>0, a 2, a 3<0$ dan a $<1$

Di mana :

A1d HBRt / At = Elastisitas (respon) areal jangka pendek E(A,P)

Elastisitas (respon) areal jangka panjang $\mathrm{E}(\mathrm{A}, \mathrm{P})=$ Ald HBRt / At =al HBRt / At a4=1-d, sehingga nilai $\mathrm{d}$ dapat ditentukan.

Respon produktifitas diturunkan melalui cara yang sama seperti respon areal. Produktifitas padi diduga sebagai fungsi dari lag harga beras, (HBRt1). Trend teknologi (T1). Jumlah penggunaan pupuk (JPUt), Areal panen (LAPt). Persamaan produktivitas ini dapat dispesifikasikan sebagai berikut.

$\mathrm{Yt}=\mathrm{b}+\mathrm{b} 1$ HBRt$-1+\mathrm{b} 2 \mathrm{~T} 1+\mathrm{b} 3 \mathrm{JPUt}+\mathrm{b} 4 \mathrm{LAPt}+$ yt-1

$\mathrm{Y}^{\prime} \mathrm{t}=$ Produktifitas yang diharapkan pada tahun $\mathrm{t}$

Perbedaan produktifitas yang sebenarnya merupakan proporsi tertentu dari perubahan produktivitas yang diharapkan.

Yt-Yt-1 = $\mathrm{t}(\mathrm{Yt}-\mathrm{Yt}-1)$

$\mathrm{Yt}=\mathrm{tY} \mathrm{Y}^{\prime} \mathrm{t}-(1-\mathrm{t}) \mathrm{Yt}-1$

Persamaan (5) disubstitusikan ke dalam persamaan (6) akan diperoleh:

$\mathrm{Yt}=\mathrm{t}\{\mathrm{b}+\mathrm{b} 1$ HBRt $-1+\mathrm{b} 2 \mathrm{~T} 1+\mathrm{b} 3 \mathrm{JPUt}+\mathrm{b} 4 \mathrm{LAPt}+$ vt $\}+$ b5Yt-1+et

$\mathrm{Yt}=\mathrm{tb}+\mathrm{tb} 1$ HBRt $-1+\mathrm{tb} 2 \mathrm{~T} 1+\mathrm{tb} 3 \mathrm{JPUt}+\mathrm{tb} 4$ LAPt + b5Yt-1 +et

Tanda yang diharapkan:

b1, b2, b3, b4 > O dan $\mathrm{O}<\mathrm{b} 5<1$

Dimana:

$\mathrm{Yt}=$ produktivitas padi ( ton $/ \mathrm{ha}$ ) pada tahun $\mathrm{t}$

HBRt-1 = Harga Beras $(\mathrm{Rp} / \mathrm{kg})$ pada tahun ke $\mathrm{t}-1$

$\mathrm{Tt}=$ Trend teknologi $(1-25)$

At $=$ Luas Areal panen (000) ha pada tahun $t$

Yt-1 = lag produktuivitas padi (ton/ha) pada tahun $\mathrm{t}$

$\mathrm{E} 1=$ peubah pengganggu

Elastisitas jangka pendek :

$$
b_{1} \frac{H B R_{t-1}}{Y t}
$$

Elastisitas jangka panjang :

$$
\text { bt } \frac{H B R_{t-1}}{1-Y_{t-1}}
$$

Data yang digunakan dalam studi ini adalah data Time Series dari tahun 1991 sampai dengan 2015 (25 tahun). Data tersebut meliputi data harga beras, harga beras tahun sebelumnya, harga pupuk urea, harga jagung, trend teknologi, jumlah penggunaan pupuk dan data luas areal panen, produktivitas padi dan produktivitas tahun sebelumnya. Studi ini menggunakan modul ekonometrika dengan metode OLS. Bentuk fungsional yang digunakan adalah fungsi double log ( log ganda). Salah satu sifat menarik dari log ganda / double $\log$ adalah bahwa koefisien bi sekaligus sebagai ukuran elastisitas $\mathrm{Y}$ dan dalam jangka pendek disbut juga elastistisitas konstan (Gudjarati, 2006). Dilanjutkan dengan melakukan estimasi yang digunakan untuk mencari elastisitas jangka pendek dan jangka panjang, dalam rangka analisa respon penawaran.

\section{HASIL DAN PEMBAHASAN}

Hasil Pendugaan pada persamaan luas areal menunjukkan bahwa tanda parameter sebagian besar sesuai dengan yang diharapkan kecuali untuk trend teknologi dan luas areal panen tanda parameter dugaan pada luas areal juga sesuai dengan yang diharapkan dan signifikan pada taraf $5 \%$ kecuali variabel harga jagung. Persamaan dugaan respon areal ini sudah dapat diterima dan terlihat koefisien determinasi yang disesuaikan sebesar 92,7\%.

Elastisitas harga jagung terhadap luas panen dalam jangka pendek adalah 0.026 dan jangka panjang sebesar 0.049 . Hal ini menunjukkan bahwa jika harga jagung naik $1 \%$ akan menaikkan luas areal padi dalam jangka pendek 0,026 persen dan dalam jangka panjang 0,049 persen. Hal ini mengindikasikan bahwa jagung bukan merupakan komoditi yang berkompetisi dengan padi sawah, terlihat juga dari tanda parameter yang positif, berarti jika harga jagung naik, seharusnya produksi jagung naik, tetapi produksi padi juga ikut naik. Nilai elastisitas harga jagung terhadap produk si padi adalah (+) dan inelastic.

NIlai elastisitas harga beras terhadap luas areal adalah 0,079 dalam jangka pendek dan 0,151 dalam jangka panjang, nilai ini lebih responsive disbanding dengan nilai elastisitas harga jagung yang mengindikasikan bahwa respon petani terhadap harga beras lebih tinggi ( lebih responsive) daripada elastisitas harga jagung dengan nilai elastisitas 0,026 dalam jangka pendek dan 0,049 dalam jangka panjang.

Dari hasil pendugaan menunjukkan ada hubungan yang terbalik antara luas areal panen dan produktifitas (walaupun dalam pengaruh yang kecil).Semakin tinggi luas areal panen, semakin menurun produktivitas, terlihat dari elastisitas jangka pendek -0,029 dan jangka panjang -0,161.

Harga beras tahun sebelumnya sangat nyata pengaruhnya terhadap produktivitas padi sawah, hal ini menunjukkan bahwa factor harga masih memiliki 
pengaruh penting pada peningkatan partisipasi petani dalam mengelola usaha taninya. Tanda parameter yang diharapkan menunjukkan kesesuaian dengan hipotesa.

Harga beras tidak nyata (tidak signifikan) pengaruhnya terhadap luas areal panen, walaupun tanda koefisien regresi sudah seperti yang diharapkan, hal ini mengindikasikan semakin terbatasnya lahan untuk kegiatan pertanian padi sawah, secara fatual telah terjadi penurunan secara drastis penguasaan lahan pertanian pada setiap rumah tangga (16\%/tahun). Berbagai upaya dilakukan dalam meningkatkan akses lahan bagi petani yang berlahan sempit. Pemerintah harus mengintensifkan beberapa kebijakan diantaranya melalui pembukaan lahan baru dan implementasi reforma lahan (Sudarianto ef al 2009). Hal ini menandaskan bahwa lahan merupakan penyumbang utama pendapatan rumah tangga petani namun karena penguasaan lahan yang semakin sempit maka pendapatan dari lahan semakin menyusut.

Studi ini juga menunjukkan bahwa elastisitas harga pupuk area terhadap luas areal adalah inelastic (0,070 dalam jangka pendek dan 0,1338 dalam jangka panjang), hal ini menunjukkan bahwa harga pupuk masih berpengaruh terhadap keputusan petani dalam meningkatkan produksi usaha taninya, karena jika harga pupuk naik, penggunaan pupuk menurun maka luas areal panen akan menurun (-).

Tabel 1 Hasil Empiris Respon Luas Areal Padi Dan Produktivitas Padi di Indonesia

\begin{tabular}{|l|l|l|l|l|l|}
\hline \multicolumn{1}{|c|}{ Ket } & Notasi & Koefisien & $\mathrm{t}$ & $\begin{array}{l}\text { Elastisitas Jk. } \\
\text { Pendek }\end{array}$ & $\begin{array}{l}\text { Elastisitas Jk. } \\
\text { Panjang }\end{array}$ \\
\hline Luas Areal & LAt & - & & - & \\
\hline Konstanta & - & 4,583 & 4,147 & - & \\
\hline Harga Beras & HBRt & 0,079 & 2,034 & 0,079 & 0,151 \\
\hline Harga Jagung & HJGt & 0,026 & 0,412 & 0,026 & 0,049 \\
\hline Harga Pupuk & HPDt & $-0,070$ & $-2,307$ & $-0,070$ & 0,1338 \\
\hline $\begin{array}{l}\text { Luas Areal Panen } \\
\text { tahun sebelumnya }\end{array}$ & LAPt-1 & 0,477 & 3.408 & 0,477 & 0,912 \\
\hline
\end{tabular}

Tabel 2 Hasil Empiris Respon Produksi Padi di Indonesia

\begin{tabular}{|l|l|l|l|l|l|}
\hline Ket & Notasi & Koef. & $\mathrm{t}$ & $\begin{array}{l}\text { Elastisitas } \\
\text { Jk. Pendek }\end{array}$ & $\begin{array}{l}\text { Elastisitas } \\
\text { Jk. Panjang }\end{array}$ \\
\hline Produktivitas & Yt & & & & \\
\hline Konstanta & - & 0,310 & 0,290 & & \\
\hline Harga Beras thn sebelumnya & HBRt-1 & 0,049 & 3,015 & 0,049 & 0,2722 \\
\hline Trend Teknologi & Tt & $-0,037$ & $-2,346$ & $-0,037$ & $-0,5053$ \\
\hline Jumlah Penggunaan Pupuk & JPUt & 0,069 & 0,989 & 0,069 & 0,383 \\
\hline Luas Areal Panen & APt & $-0,029$ & $-0,224$ & $-0,029$ & $-0,161$ \\
\hline Produktivitas thn sebelumnya & Yt-1 & 0,820 & 6,553 & 0,820 & 4,5 \\
\hline
\end{tabular}

Hasil estimasi terhadap respon produktivitas belum mencerminkan kondisi yang sebenarnya, hal ini ditunjukkan oleh dua tanda parameter yang tidak sesuai dengan yang diharapkan dan dari uji signifikansi, dua variabel tidak nyata pengaruh, yakni variabel penggunaan pupuk areal dan luas arela panen padi.

Luas areal panen padi tidak berpengaruh nyata terhadap produktivitas padi $(\alpha=0,05 \%)$. Hal ini selaras dengan nilai elastisitas produktivitas terhadap perubahan luas areal yang sangat kecil bahkan bernilai negative $(0,029$ dalam jangka pendek dan 0,161 dalam jangka panjang).

Teknologi dalam peningkatan produktivitas usaha tani padi tampaknya tidak dapat dijelaskan hanya oleh variabel trend teknologi, diperlukan kekhususan data tentang jenis teknologi yang digunakan dalam usaha tani padi sawah.

Hasil studi ini menunjukkan bahwa penambahan jumlah penggunaan pupuk meningkatkan produktivitas dengan elastisitas jangka pendek, 0,069 dan jangka panjang 0,383, mengindikasikan bahwa masih diperlukan peningkatan penggunaan pupuk yang sesuai dengan rekomendasi pemerintah

\section{KESIMPULAN}

Variabel harga berpengaruh nyata pada produktivitas akan tetapi tidak berpengaruh nyata pada luas areal panen. Nilai elastisitas luas areal panen adalah 0,151 dalam jangka panjang lebih kecil daripada nilai elastisitas produktivitas dalam jangka panjang sebesar 0,271. Hal ini mengindikasikan bawa upaya peningkatan produksi melalui intensifikasi masih dapat ditingkatkan sedangkan upaya peningkatan produksi dengan penambahan luas areal tampaknya hanya berpengaruh kecil.

Pada kenyataannya, penyusutan lahan padi sawah terjadi dari tahun ke tahun, sehingga perlu dilakukan upaya pelarangan konversi lahan pertanian 
(terutama di Pulau Jawa). Potensi lainnya adalah dengan perluasan lahan padi sawah (terutama di Luar Pulau Jawa) yang harus didukung oleh pembangunan infrastruktur serta insentif penyediaan sumber modal yang memungkinkan petani untuk mengadopsi teknologi yang direkomendasikan

\section{DAFTAR PUSTAKA}

Amalia, Dkk (2019). Badan Pusat Statistik Jakarta.

Badan Pusat Statistik, 1991 - 2015, Statistik Indonesia, BPS. Jakarta

Badan Pusat Statistik, 2005. Luas Penggunaan Lahan, BPS. Jakarta.

Gujaraty, D, 1978. Theory of economics Harper and Row Publisher Inc, New York.

Irawa, A. Analisis Respon Penawaran Padi sawah dan Ladang di jawa dan luar jawa.

Jalil, S (2018). Kementrian Koordinator bidang perekonomian, Jakarta.

Koytsoyiannis A. 1978. Theory of Econometrics Harper and Row Publisher Inc, New York.

Nerlove, M, 1958. The Dynamics of supply : estimation of farmers. Response to Price the John Hopkin Press/Boldtimore ___ 1958: Distributed lags and estimation of Long Run Supply and Demand Elosticities.

Sudaryanto, T. SH, Susilawati, 2009. Increasing Number of small farms : Decline of persistence, Universitu of Kent Coutenbury, UK. 